\title{
DIFFERENT METHODS FOR MEASURING EVAPORATION IN A TROPICAL RESERVOIR: THE CASE OF THE GAVIÃO RESERVOIR IN THE STATE OF CEARÁ $^{1}$
}

\author{
GABRIELA PINHEIRO FEITOSA ${ }^{2 *}$, JOSÉ CARLOS DE ARAÚJO² ${ }^{2}$, MÁRIO UBIRAJARA GONÇALVES BARROS ${ }^{3}$
}

\begin{abstract}
Studies that allow the estimation of evaporation in reservoirs represent an important action for the adequate management of water resources. Thus, this study aimed at estimating evaporation in the tropical reservoir Gavião, located in the municipality of Pacatuba, Ceará, Brazil, and to verify the effect of these estimates on the water availability of the reservoir using the VYELAS model. The results of Penman's methods and the Water Balance were compared with the values obtained from the hydrostatic pressure sensor, the most accurate. It was possible to verify that, in relation to the pressure difference method, all the conventional methods overestimate the evaporation in the reservoir. The method that presented estimates closer to those obtained by the pressure difference sensor was that of Penman, based on data from an onboard station in the lake, with a deviation of only $12 \%$. The method of water balance also presented reliable results for monthly average. The two methods usually accepted in the evaporation calculation (water balance ignoring the infiltration; and Penman's method for meteorological station data on land distant from the lake) presented the most disturbing evaporation values significantly altering the water availability. The results of the VYELAS model showed that evaporated flows, estimated by several methods, exceeded the reference flow by up to $83 \%$. The results demonstrate the great sensitivity of the estimate of water availability in relation to the evaporation rate in the lake.
\end{abstract}

Keywords: Hydrology of lentic environments. Water balance of semi-arid regions. VYELAS Model.

\section{EVAPORAÇÃO EM RESERVATÓRIO TROPICAL MEDIDA POR DIFERENTES MÉTODOS: O CASO DO AÇUDE GAVIÃO, CE}

\begin{abstract}
RESUMO - Estudos que possibilitem a estimativa da evaporação em reservatórios representam uma importante ação para o adequado gerenciamento dos recursos hídricos. Dessa forma, este estudo objetivou estimar a evaporação no reservatório tropical Gavião, localizado no município de Pacatuba, Ceará, Brasil, e verificar o efeito dessas estimativas sobre a disponibilidade hídrica do reservatório utilizando o modelo VYELAS. Os resultados dos métodos de Penman e do Balanço Hídrico foram comparados com os valores obtidos do sensor de pressão hidrostática, o mais preciso. Foi possível constatar que, em relação ao método de diferença de pressão todos os métodos convencionais superestimam a evaporação no reservatório. O método que apresentou estimativas mais próximas daquelas obtidas pelo sensor de diferença de pressão foi o de Penman, baseado nos dados de uma estação embarcada no lago, com desvio de apenas $12 \%$. O método do balanço hídrico também apresentou resultados confiáveis para média mensal. Os dois métodos usualmente aceitos no cálculo de evaporação (balanço hídrico desprezando-se a infiltração; e método de Penman para dados de estação meteorológica em terra distante do lago) apresentaram os valores mais destoantes de evaporação alterando significativamente a disponibilidade hídrica. Os resultados do modelo VYELAS demostraram que as vazões evaporadas, estimadas por diversos métodos, superaram em até $83 \%$ a vazão de referência. Os resultados também demonstram a grande sensibilidade da estimativa de disponibilidade hídrica em relação à taxa de evaporação no lago.
\end{abstract}

Palavras-chave: Hidrologia de ambientes lênticos. Balanço hídrico em regiões semiáridas. Modelo VYELAS.

\footnotetext{
${ }^{*}$ Corresponding author

${ }^{1}$ Received for publication in $01 / 30 / 2020$; accepted in $11 / 06 / 2020$.

Paper extracted from the master dissertation of the first author.

${ }^{2}$ Department of agricultural engineering, Universidade Federal do Ceará, Fortaleza, CE, Brazil; gabipfeitosa@gmail.com - ORCID: 00000002-0653-9379, jcaraujo@ufc.br-ORCID: 0000-0002-2649-151X.

${ }^{3}$ Operational Development Management, Companhia de Gestão dos Recursos Hídricos do Ceará, Fortaleza, CE, Brazil; mariobarros86@hotmail.com-ORCID: 0000-0001-5763-8951.
} 


\section{INTRODUCTION}

Evaporation is one of the principal processes involved in the water and heat balance of reservoirs, and is responsible for transferring large amounts of water and energy to the atmosphere via latent heat flow. In reservoirs, this process is seen as a loss by the sector for water resource management and planning, since it represents an outflow of water in the local water balance, and in tropical lakes represents a significant volume of water that might otherwise be made available for human activity. There is great pressure to use this source, especially in arid and semi-arid climates, which suffer from a limited water supply and recurrent drought events, where evaporation reduces an often-limited stock of water (VIEIRA et al. 2016; LEÃO et al. 2013; LEITÃO; OLIVEIRA; LEITÃO 2007; CAMPOS, 2010; CHOW; MAIDMENT; MAYS 1988).

Understanding loss from evaporation is of great relevance when adapting policies of water resource management, and the operation and sizing of reservoirs. In addition, evaporation in tropical reservoirs plays an important role in water quality, which can be affected by the higher concentration of pollutants, and which must be considered when managing this asset (VIEIRA et al., 2016). Accurate knowledge of evaporation in reservoirs is also essential to assess the impact of climate change on society (PADRÓN et al., 2020; XU et al., 2020).

Actual evaporation on a free water surface is difficult to measure, even for small reservoirs (MCJANNET et al., 2017). There is a shortage of experimental studies on the physical processes involved, and it is possible to list various limitations on estimating evaporation, such as the uncertainty of calculating the water balance, and the low density of weather stations when using indirect methods (twelve stations for $150,000 \mathrm{~km}^{2}$ in Ceará). These data are therefore often reduced to mere references, and are frequently estimated using empirical relationships based on climate parameters (temperature, solar radiation and wind speed, among others) from relatively distant regions, which do not represent the conditions found on the free surface of the reservoir, and as such, do not represent the actual rate of evaporation of the reservoir (CAMPOS, 2010).

According to Vieira et al. (2016), it is estimated that in the Sobradinho Reservoir, which dams the River São Francisco, the mean annual flow rate due to evaporation is around $203 \mathrm{~m}^{3} \cdot \mathrm{s}^{-1}$. By comparison, the authorised transposition rate for the waters of the River São Francisco is $26 \mathrm{~m}^{3} \cdot \mathrm{s}^{-1}$. Therefore, an error of thirteen percent when estimating evaporation in the reservoir would give the same flow rate as the transposition rate, in effect underlining the importance of a more-accurate understanding of the evaporation rates of reservoirs.

The aim of this study was to estimate evaporation in the tropical Gavião Reservoir, located in the district of Pacatuba, Ceará, Brazil, employing various methods: (i) Penman, using three stations located at different places; (ii) the water balance, for two hypotheses of infiltration; and (iii) the hydrostatic pressure sensor. A further aim was to verify the effect of these estimates on water availability in the reservoir, using the VYELAS model.

\section{MATERIAL AND METHODS}

\section{Description of the study area}

The Gavião Reservoir is located in the Metropolitan Region of Fortaleza (MRF), between the districts of Pacatuba and Itaitinga, in the state of Ceará. The reservoir has a capacity of $33.3 \mathrm{hm}^{3}$ and is part of the Metropolitan Basin Network. Belonging to the coastal region, it has a warm, subhumid tropical climate, which is predominantly characterised as warm and stable, with mean annual temperatures ranging between $26^{\circ} \mathrm{C}$ and $28^{\circ} \mathrm{C}$. Close to the equator (at $3.9258^{\circ} \mathrm{S}$ ), the region has high insolation, varying from 2,650 to $3,000 \mathrm{~h} . \mathrm{yr}^{-1}$, which affords high potential evaporation. It is mainly characterised by the rainfall concentrated during the first half of the year, with the rainy season historically lasting from January to May, and a hot, dry second semester, characterised by drought. Figure 1 shows the location of the Gavião Reservoir and of the weather stations employed in the study.

The period chosen for the study was from 11 October 2019 to 11 December 2019, a dry period in the region. Figure $2 \mathrm{a}$ shows the seasonal rainfall distribution in the study region, and Figure $2 b$ shows the daily rainfall totals during the study period, measured by the weather stations. The dry period was chosen for two reasons: a reduction in the uncertainties typical of the rainy season, caused by spatial variations in the rainfall and by the water supplied from the rivers; and because the method for estimating water availability (ARAÚJO; GÜNTNER; BRONSTERT, 2006; CAMPOS, 2010) uses only the evaporation of the dry period. 


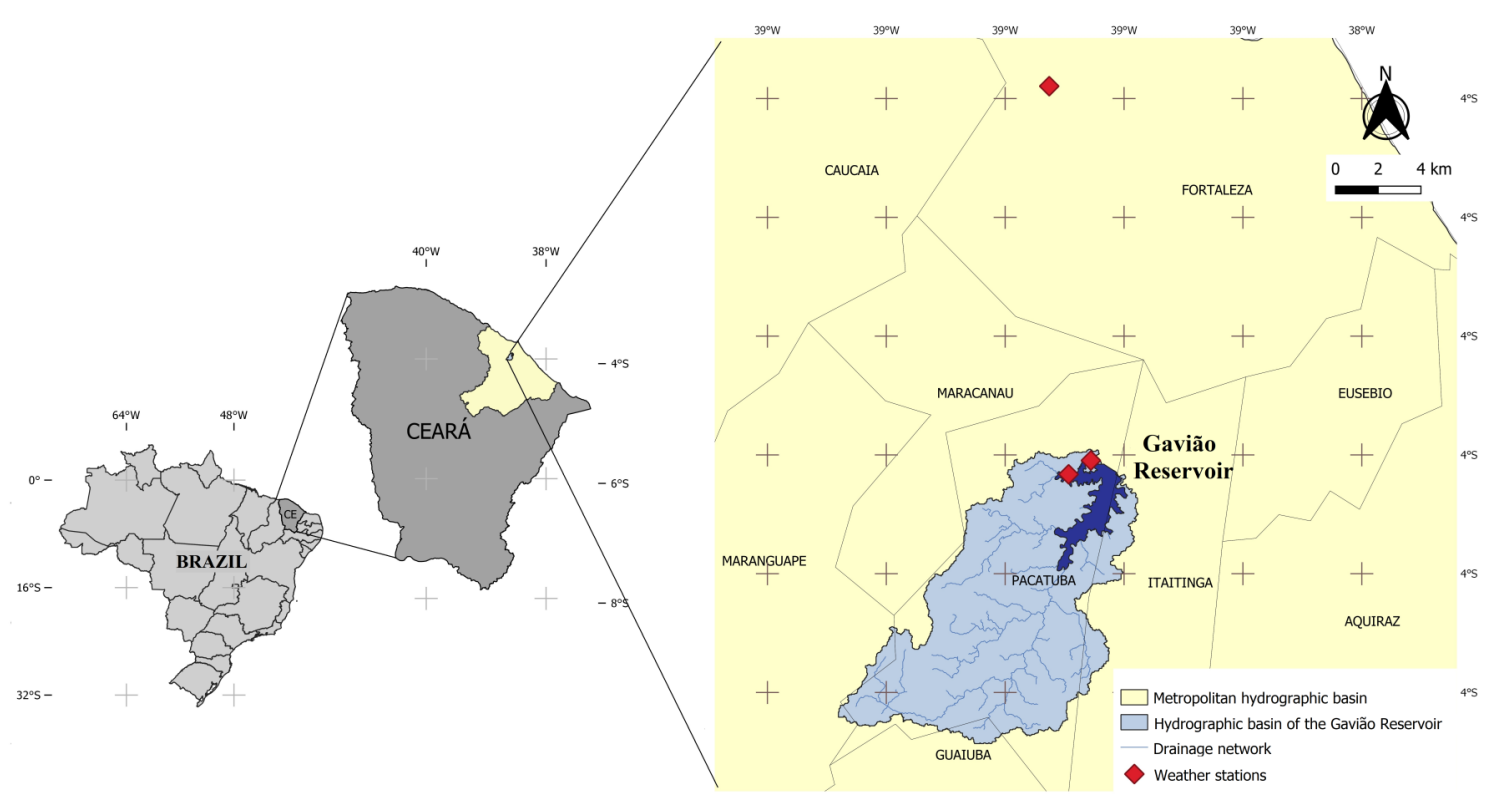

Figure 1. Location of the Gavião Reservoir and the weather stations in Pacatuba, Ceará, Brazil.
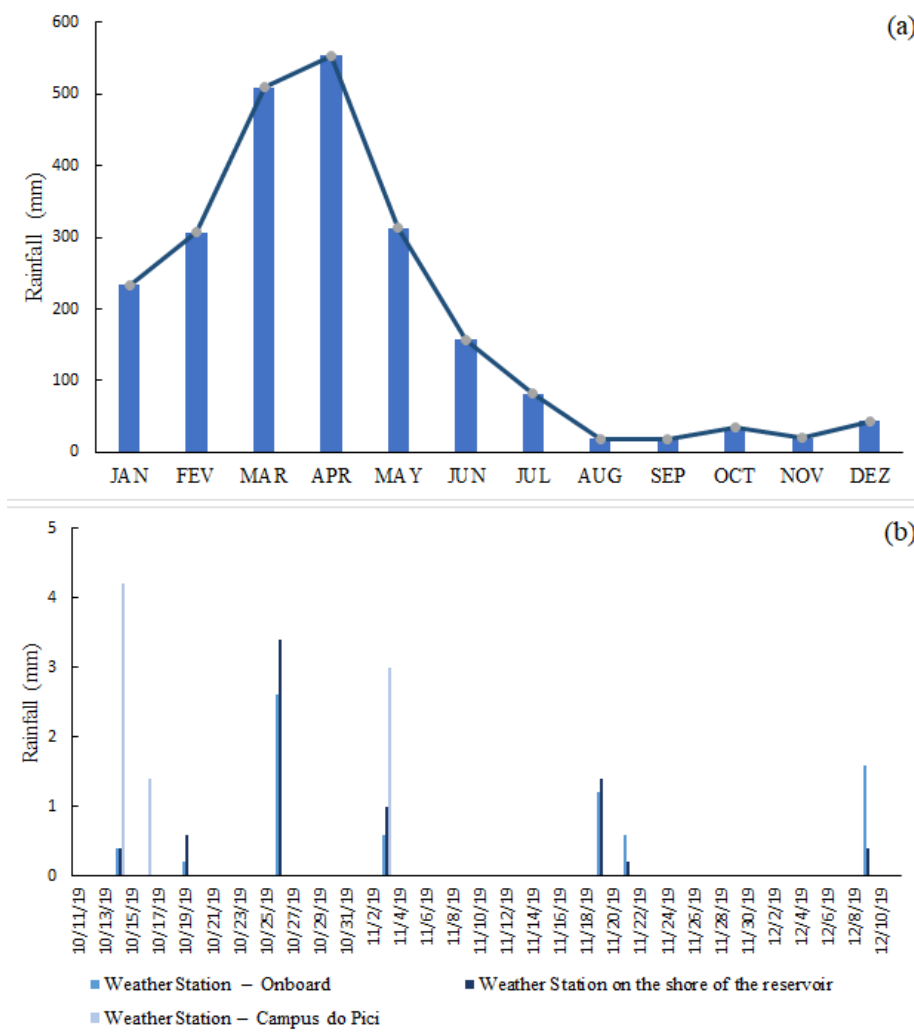

Figure 2. (a) Mean monthly rainfall for the district of Pacatuba, Ceará, Brazil; (b) daily total rainfall from 11 October 2019 to 11 December 2019 measured by the different weather stations used in the study.

\section{Estimating evaporation by the Penman method}

The meteorological data used in this study for calculating evaporation were obtained from three weather stations. Two of the stations were automatic (AWS), one of which was placed on board a floating structure in the reservoir, and the other, a land station, about $400 \mathrm{~m}$ from the free water surface of the reservoir. The third weather station was conventional (CWS), and was installed on the Campus do Pici of the Federal University of Ceará (UFC), in Fortaleza, $19 \mathrm{~km}$ from the reservoir. Information on the stations is shown in Table 1. 
Table 1. Information on the weather stations used in the study.

\begin{tabular}{lcccc}
\hline \multicolumn{1}{c}{ Station } & $\begin{array}{c}\text { Latitude } \\
(\text { degrees })\end{array}$ & $\begin{array}{c}\text { Longitude } \\
(\text { degrees })\end{array}$ & $\begin{array}{c}\text { Altitude } \\
(\mathrm{m})\end{array}$ & Distance from the surface of the water \\
\hline Onboard automatic station & -3.908 & -38.573 & 37 & On the water (zero) \\
Nearby automatic station & -3.902 & -38.564 & 52 & $400 \mathrm{~m}$ \\
Distant automatic station & -3.745 & -38.581 & 20 & $19,000 \mathrm{~m}$ \\
\hline
\end{tabular}

The choice of location for the onboard station followed the safety criteria of the floating station and was close to the sensor of the hydrostatic pressure exerted by the water column and the local atmospheric pressure (equipment used in the differential pressure method).

For the automatic stations, data for the maximum, minimum and mean temperatures, relative humidity, wind speed, rainfall and global solar radiation were measured every five minutes. For the conventional station, synoptic observation data for the maximum, minimum and mean temperatures, relative humidity, wind speed, rainfall and insolation were obtained at 12:00, 18:00 and 24:00 UTC.

The model proposed by Penman et al. (1948) considers mass and energy transfer, and is represented by Equation 1 .

$$
\mathrm{E}=86.4 \frac{\Delta}{(\Delta+\gamma)} \cdot\left(\frac{\mathrm{R}_{\mathrm{n}}}{\lambda . \rho}\right)+\frac{\gamma}{\Delta+\gamma} \cdot\left(0.26\left(0.5+0.54 \mathrm{u}_{2}\right)\right)\left(\mathrm{e}_{\mathrm{s}}-\mathrm{e}_{\mathrm{a}}\right)
$$

In Equation 1, $\mathrm{E}$ is the rate of evaporation, $\left(\mathrm{mm}_{\mathrm{day}}{ }^{-1}\right) ; \Delta$ is the slope of the vapour pressure curve, $\left(\mathrm{kPa} .{ }^{\circ} \mathrm{C}^{-1}\right) ; \gamma$ is the psychrometric parameter, $\left(\mathrm{kPa} .{ }^{\circ} \mathrm{C}^{-1}\right) ; \mathrm{R}_{\mathrm{n}}$ is the radiation balance, $\left(\mathrm{W} \cdot \mathrm{m}^{-2}\right) ; \lambda$ is the latent heat of vaporisation, $\left(\mathrm{MJ}^{\mathrm{k}} \mathrm{kg}^{-1}\right) ; \rho$ is the specific weight of the water $\left(\mathrm{kg} \cdot \mathrm{m}^{-3}\right) ; \mathrm{u}_{2}$ is the wind speed measured $2 \mathrm{~m}$ above the surface, $\left(\mathrm{m}_{\mathrm{s}} \mathrm{s}^{-1}\right)$; $\mathrm{e}_{\mathrm{s}}$ is the saturated vapour pressure at air temperature, $(\mathrm{kPa})$; and $\mathrm{e}_{\mathrm{a}}$ is the effective air vapour pressure, $(\mathrm{kPa})$. The variables for Equation 1 were obtained following the methodology described by Chow, Maidment and Mays (1988).

At the weather station that was far from the reservoir (Campus do Pici), the wind speed was measured at a height of $10 \mathrm{~m}$. The wind speed at $2 \mathrm{~m}$ was estimated based on the Prandtl-von Kármán logarithmic law (Equation 2), which describes the distribution of the longitudinal velocity of a turbulent fluid flow close to the boundary layer.

In Equation 2, $\mathrm{z}$ is the height above the surface $(\mathrm{m}) ; \mathrm{u}_{\mathrm{z}}$ is the mean wind speed at height $\mathrm{z}$ $\left(\mathrm{m} . \mathrm{s}^{-1}\right) ; \mathrm{z}_{0}$ is the surface roughness parameter $(\mathrm{m}) ; \mathrm{k}$ is the von Kármán constant $(\mathrm{k} \approx 0.40)$; and $u^{*}$ is the frictional speed $\left(\mathrm{m} . \mathrm{s}^{-1}\right)$ given by Equation 3 , where $\tau$ is the shear stress at the flow boundary layer $(\mathrm{Pa})$, and $\rho_{\text {air }}$ is the specific weight of the air $\left(\mathrm{kg} \cdot \mathrm{m}^{-3}\right)$.

$$
\begin{gathered}
\mathrm{u}_{\mathrm{z}}=\frac{\mathrm{u} *}{\mathrm{k}} \cdot \ln \left(\frac{\mathrm{z}}{\mathrm{z}_{0}}\right) \\
\mathrm{u} *=\sqrt{\frac{\tau}{\rho_{\mathrm{air}}}}
\end{gathered}
$$

The radiation balance $\left(R_{n}\right)$ at the conventional station was calculated by Equation 4 , where $R_{n s}$ is the shortwave radiation balance $\left(\mathrm{W} . \mathrm{m}^{-2}\right)$, calculated from Equation 5, and $R_{n l}$ is the longwave radiation balance $\left(\mathrm{W} . \mathrm{m}^{-2}\right)$ calculated from Equation 6 . Equation 7 was used to calculate the global solar radiation $\left(\mathrm{R}_{\mathrm{s}}\right)$, as per the methodology suggested by Angstrom (1924). At the automatic stations, the radiation balance was measured directly using the installed sensor.

$$
\begin{gathered}
\mathrm{R}_{\mathrm{n}}\left(\mathrm{W} \cdot \mathrm{m}^{-2}\right)=\mathrm{R}_{\mathrm{ns}}-\mathrm{R}_{\mathrm{nl}} \\
\mathrm{R}_{\mathrm{ns}}\left(\mathrm{W} \cdot \mathrm{m}^{-2}\right)=(1-\propto) \cdot \mathrm{R}_{\mathrm{s}} \\
\mathrm{R}_{\mathrm{nl}}\left(\mathrm{W} \cdot \mathrm{m}^{-2}\right)=-\left[4.903 \cdot 10^{-9} \cdot \mathrm{T}_{\mathrm{a}}^{4}\left(0.34-0.14 \sqrt{\mathrm{e}_{\mathrm{a}}}\right)\left(0.1+0.9 \frac{\mathrm{n}}{\mathrm{N}}\right)\right] \\
\mathrm{R}_{\mathrm{s}}=\mathrm{Q}_{\mathrm{o}} \cdot\left(\mathrm{w}+\mathrm{y} \cdot \frac{\mathrm{n}}{\mathrm{N}}\right)
\end{gathered}
$$

In Equations 4, 5, 6 and 7, $\alpha$ is the water albedo, taken as equal to $6 \% ; \mathrm{R}_{\mathrm{s}}$ is the global solar radiation $\left(\mathrm{W} . \mathrm{m}^{-2}\right)$; Ta is the air temperature (Kelvin); $\mathrm{e}_{\mathrm{a}}$ is the air vapour pressure $(\mathrm{kPa}) ; \mathrm{n}$ is the number of hours of sunshine $(\mathrm{h})$; $\mathrm{N}$ is the photoperiod $(\mathrm{h})$; $\mathrm{Q}_{\mathrm{o}}$ is the radiation at the top of the atmosphere (MJ.m ${ }^{2}$.day $\left.^{-1}\right)$; w and $y$ are Angstrom parameters, taken to be $\mathrm{w}=0.2608$ and $\mathrm{y}=0.3092$ for the metropolitan region of Fortaleza, as per Aguiar et al. (1999).

\section{Estimating evaporation by the water balance method}

During the measurement period (October December), which corresponds to the dry season, the flow rate from the River Cocó (principal natural tributary of the Gavião Reservoir) is negligible, and was considered to be zero. Therefore, the only inflow to the reservoir during the dry period is transferred from the Riachão-Pacoti system and the Acarape do Meio Reservoir, located in Ceará. During the measurement period, the spill from the reservoir was always zero, as verified in situ. Thus, the water balance equation can be simplified using Equation 8 to estimate the evaporation flow rate. The daily rate of evaporation is given by Equation 9 . 


$$
\begin{gathered}
\mathrm{Q}_{\mathrm{E}}=\mathrm{Q}_{\mathrm{ENT}}-\left(\frac{\mathrm{dV}}{\mathrm{dt}}+Q_{R}+Q_{I}\right) \\
\mathrm{E}=\frac{\mathrm{Q}_{\mathrm{E}}}{\mathrm{A}_{\mathrm{res}}}
\end{gathered}
$$

In Equations 8 and $9, \mathrm{Q}_{\mathrm{E}}$ is the flow rate evaporated from the reservoir $\left(\mathrm{m}^{3}\right.$.day $\left.{ }^{-1}\right)$; $\mathrm{Q}_{\mathrm{ENT}}$ is the inflow rate to the reservoir $\left(\mathrm{m}^{3} \cdot \mathrm{day}^{-1}\right)$; $\frac{d V}{d t}$ is the change in the volume of the reservoir over time $\left(\mathrm{m}^{3}\right.$.day $\left.{ }^{-1}\right) ; \mathrm{Q}_{\mathrm{R}}$ is the flow rate removed from the reservoir $\left(\mathrm{m}^{3}\right.$.day $\left.{ }^{-1}\right)$; $\mathrm{Q}_{\mathrm{I}}$ is the rate of infiltration plus percolation through the wall of the dam $\left(\mathrm{m}^{3} \cdot \mathrm{day}^{-1}\right) ; \mathrm{E}$ is the rate of evaporation (m.day ${ }^{-1}$ ); and $A_{\text {res }}$ is the area of the reservoir $\left(\mathrm{m}^{2}\right)$ (varying over time). The inflow rate to the reservoir $\left(\mathrm{Q}_{\mathrm{ENT}}\right)\left(\mathrm{m}^{3}\right.$.day $\left.{ }^{-1}\right)$ is given by the sum of the transposition flow rate from the Pacoti-Riachão System, the flow rate from the Acarape do Meio Reservoir, and the flow rate generated by direct precipitation onto the free surface.

Molle and Cadier (1992) found that the mean specific infiltration rate (i.e. the flow rate per unit area) in semi-arid reservoirs in Brazil corresponded to $1 / 3$ of the evaporation of a class A pan. The literature (for example, see MAMEDE et al., 2012) indicates that the rate of evaporation in a semi-arid reservoir is approximately 0.70 times the evaporation of a class A pan. This shows that, on average, infiltration is almost equal to half the evaporation in a semi-arid lake. In the scope of the present research therefore, infiltration was taken as varying from zero (CAMPOS, 2010) to $100 \%$ of the evaporation, so that the mean is close to $50 \%$ of the evaporation rate, as determined in the study by Molle and Cadier (1992). The maximum evaporation flow rate is therefore given by Equation 10, a special case of Equation 8 for the null-infiltration hypothesis.

$$
Q_{E, M A X}=Q_{E N T}-\left(\frac{d V}{d t}+Q_{R}\right)
$$

By making the infiltration flow rate (I) equal to the evaporation flow rate in Equation 8, the minimum evaporated flow rate is obtained, given by Equation 11.

$$
\mathrm{Q}_{\mathrm{E}, \mathrm{MIN}}=\frac{\mathrm{Q}_{\mathrm{ENT}}-\left(\frac{\mathrm{dV}}{\mathrm{dt}}+\mathrm{Q}_{\mathrm{R}}\right)}{2}
$$

The daily data for the level, flooded area and volume of the reservoir were made available by the Water Resources Management Company of Ceará (COGERH) through its website (COGERH, 2019). To allow for continuous data, the height-area-volume curves were adjusted by polynomials based on morphological design data obtained in situ.

\section{Estimating evaporation by the hydrostatic pressure sensor method}

To estimate the evaporated depth using the differential pressure method, a pressure sensor with an accuracy of $0.1 \mathrm{~mm}$ was installed in the Gavião Reservoir coupled to an evaporimetric tank immersed in the waters of the reservoir, $60 \mathrm{~cm}$ in diameter and $60 \mathrm{~cm}$ in depth, made from a stainlesssteel plate with an internal stilling well of the same material, $10 \mathrm{~cm}$ in diameter and $60 \mathrm{~cm}$ deep, as recommended by the WMO (2018). Hydrostatic pressure data was collected automatically every 10 minutes.

The hydrostatic differential pressure method was adopted as the reference method, as it allows direct measurement of the evaporation in the reservoir and offers the best level of accuracy and precision among all the methods analysed in this study, and is therefore the most reliable. As such, using Equations 12 and 13, it is possible to calculate the changes in level inside the tank $(\Delta \mathrm{h})$ and, consequently, the rate of evaporation (E).

$$
\begin{aligned}
& \Delta \mathrm{h}=\frac{\Delta \mathrm{p}}{\rho \cdot \mathrm{g}} \\
& \mathrm{E}=\Delta \mathrm{h}+\mathrm{H}
\end{aligned}
$$

In Equations 12 and 13, $\Delta \mathrm{h}$ represents the changes in level inside the tank (m), this value is negative whenever evaporation exceeds the rainfall between measurements; $\Delta \mathrm{p}$ is the difference in hydrostatic pressure exerted by the water column $\left(\mathrm{N} \cdot \mathrm{m}^{-2}\right) ; \rho$ is the density of the water $\left(\mathrm{kg} \cdot \mathrm{m}^{-3}\right) ; \mathrm{g}$ is the acceleration due to gravity $\left(9.81 \mathrm{~m} \cdot \mathrm{s}^{-2}\right)$; and $\mathrm{H}$ is the rainfall depth for the same time interval as the pressure measurements $(\mathrm{Pa})$. The pressure changes with alterations in the water column throughout the day; therefore, by automatically measuring the hydrostatic pressure exerted by the water column and precipitation during the day, the evaporated depth can be determined. It is recommended there be a weather station a short distance from the pan that can give information about possible water input due to precipitation. In the present study, a weather station was installed $5 \mathrm{~m}$ from the pan that contained the hydrostatic pressure sensor.

\section{Statistical analysis of the data}

The rates of evaporation obtained by the various experimental methods in relation to the rates obtained by the differential pressure method were compared using simple linear regression. To analyse the accuracy of each method, the coefficient of 
determination $\left(\mathrm{R}^{2}\right)$ and the Pearson correlation coefficient (R) were used. The accuracy of the estimates, which is related to the difference between the estimated and observed values, was assessed using the index of agreement (d) proposed by Willmott, Ackleson and Davis (1985). The performance of each method was evaluated using the performance index (c) suggested by Camargo and Sentelhas (1997). The performance index is equal to the Pearson coefficient (R) multiplied by the index of agreement $(d),(c=R d)$. The closer the values for $R^{2}$, $\mathrm{d}$, and $\mathrm{c}$ approach one, the better the performance of the method.

To quantify the errors given by the estimates, the following statistical parameters were analysed: $\mathrm{ME}$, mean error $\left(\mathrm{mm} \cdot \mathrm{day}^{-1}\right)$; RMSE, root mean square error $\left(\mathrm{mm}_{\mathrm{day}}{ }^{-1}\right)$; CRM, coefficient of residual mass; SEE, standard error of the estimate. The best results are where the above parameters are closest to zero.

The mean value for each method was tested with that of the reference method at 5\% probability by the Student test to assess whether the mean values were statistically equal. All the statistical analysis was carried out using the data-analysis tool of the Excel software.

\section{Estimating water availability using the VYELAS model}

The VYELAS model (Volume-Yield Elasticity: ARAÚJO; GÜNTNER; BRONSTERT, 2006) was used in the present study to simulate water availability in the Gavião Reservoir using the evaporated rates estimated by the different methods. For these simulations, the object of which is only to compare values, transposition of the basins was not considered. It is accepted here (ARAÚJO; GÜNTNER; BRONSTERT, 2006; CAMPOS, 2010) that water availability corresponds to the regulated flow rate of the reservoir associated with a reference guarantee. As human consumption is the principal use of the water from the Gavião Reservoir, a standard of $99 \%$ was taken as the annual guarantee, as argued by Araújo, Mamede and Lima (2018). The VYELAS model simulates the water balance of the reservoir (Equations 14,15 and 16), stochastically generating a synthetic inflow rate series, and applying an operating rule whenever the level of the reservoir falls below the alert volume.

$$
\begin{gathered}
\frac{\Delta \mathrm{V}_{(\mathrm{t})}}{\Delta \mathrm{t}}=\mathrm{Q}_{\mathrm{A}}-\left(\mathrm{Q}_{\mathrm{ED}}+\mathrm{Q}_{\mathrm{U}}+\mathrm{Q}_{\mathrm{V}}\right)+\delta \mathrm{Q} \\
\mathrm{V}=\alpha \cdot \mathrm{y}^{3} \\
\bar{\alpha}=\frac{\sum \mathrm{V}_{\mathrm{i}}}{\sum\left(\mathrm{y}_{\mathrm{i}}^{3}\right)}
\end{gathered}
$$

In Equations 14, 15 and 16, $\mathrm{V}$ is the volume of the reservoir $\left(\mathrm{m}^{3}\right) ; \mathrm{t}$ is the time (year); $\mathrm{Q}_{\mathrm{A}}$ is the mean temporal inflow rate $\left(\mathrm{m}^{3} \cdot \mathrm{yr}^{-1}\right)$; $\mathrm{Q}_{\mathrm{ED}}$ is the evaporated flow rate during the dry season $\left(\mathrm{m}^{3} \cdot \mathrm{yr}^{-1}\right)$; $\mathrm{Q}_{\mathrm{U}}$ is the flow rate removed from the reservoir for use $\left(\mathrm{m}^{3} . \mathrm{yr}^{-1}\right) ; \mathrm{Q}_{\mathrm{V}}$ is the spill rate $\left(\mathrm{m}^{3} . \mathrm{yr}^{-1}\right)$; and $\delta \mathrm{Q}$ is the water exchange balance of the other inputs and outputs $\left(\mathrm{m}^{3} \cdot \mathrm{yr}^{-1}\right)$, for example, direct precipitation onto the reservoir, underground contribution, and infiltration and evaporation during the rainy season. For long-term simulations in the semi-arid region of Brazil, the term $\delta Q$ is accepted as insignificant (CAMPOS, 2010). In Equations 15 and 16, y is the height of water in the reservoir (m) and $\alpha$ is the form coefficient of the reservoir (dimensionless, Table 2).

The VYELAS model allows the water balance to be calculated in seasonal steps based on the following variables: mean annual inflow; coefficient of variation of the tributary inflow; form coefficient of the reservoir; evaporation during the dry period; storage capacity; minimum operational (alert) volume; volume at the start of the simulation; maximum and minimum values of simulated regulated flows; number of simulated regulated flows; number of simulations of the stochastic procedure. The stochastic procedure consists in generating a synthetic annual inflow rate series, for which the Monte Carlo method was used, reproducing the historical mean and the coefficient of variation of the annual outflows. Details of the flow rate generation process can be found in Araújo, Güntner and Bronstert (2006).

Flow rate data measured by COGERH (2019) were used to calculate the mean inflow rate and the coefficient of variation of the annual outflow. The coefficient of variation (CV) shown in Table 2 for the Gavião Reservoir was based on a study of the nearby Santo Anastácio Reservoir (ARAÚJO; GÜNTNER; BRONSTERT, 2006), for which measurements are available.

Table 2. Characteristics of the Gavião Reservoir, Pacatuba, Ceará, Brazil.

\begin{tabular}{lc}
\hline Characteristic & Value \\
\hline Hydrographic basin $\left(\mathrm{km}^{2}\right)$ & 97 \\
Residence time $(\mathrm{year})$ & 1.02 \\
Storage capacity $\left(\mathrm{hm}^{3}\right)$ & 33.3 \\
Form coefficient, $\alpha($ Equation 10) & 17927 \\
Mean annual inflow rate $\left(\mathrm{hm}^{3} . \mathrm{yr}^{-1}\right)$ & 32.6 \\
Coefficient of variation of annual outflow & 0.80 \\
Length of the dry season (number of days) & 214 \\
\hline
\end{tabular}


Evaporation during the dry period was estimated based on the above methods. The evaporation of the dry period shown here includes the total volume evaporated from June to December, seven months of the year, the same criterion used by Araújo, Güntner and Bronstert (2006). The maximum capacity of the reservoir corresponds to the volume stored at the height of the spillway sill, as provided by COGERH (2019). The alert volume was taken to be $5 \%$ of the maximum capacity of the reservoir (Table 2). The alert volume corresponds to the volume at which the removal flow rate is carefully checked, starting the process of rationalisation (ARAÚJO; MAMEDE; LIMA, 2018).

\section{RESULTS AND DISCUSSION}

\section{Evaporation in the reservoir}

Figure 3 shows the estimated evaporation in the Gavião Reservoir using the water balance, Penman and differential pressure methods. The grey area represents the maximum and minimum range for evaporation in the reservoir, estimated by the water balance method (Equations 10 and 11).

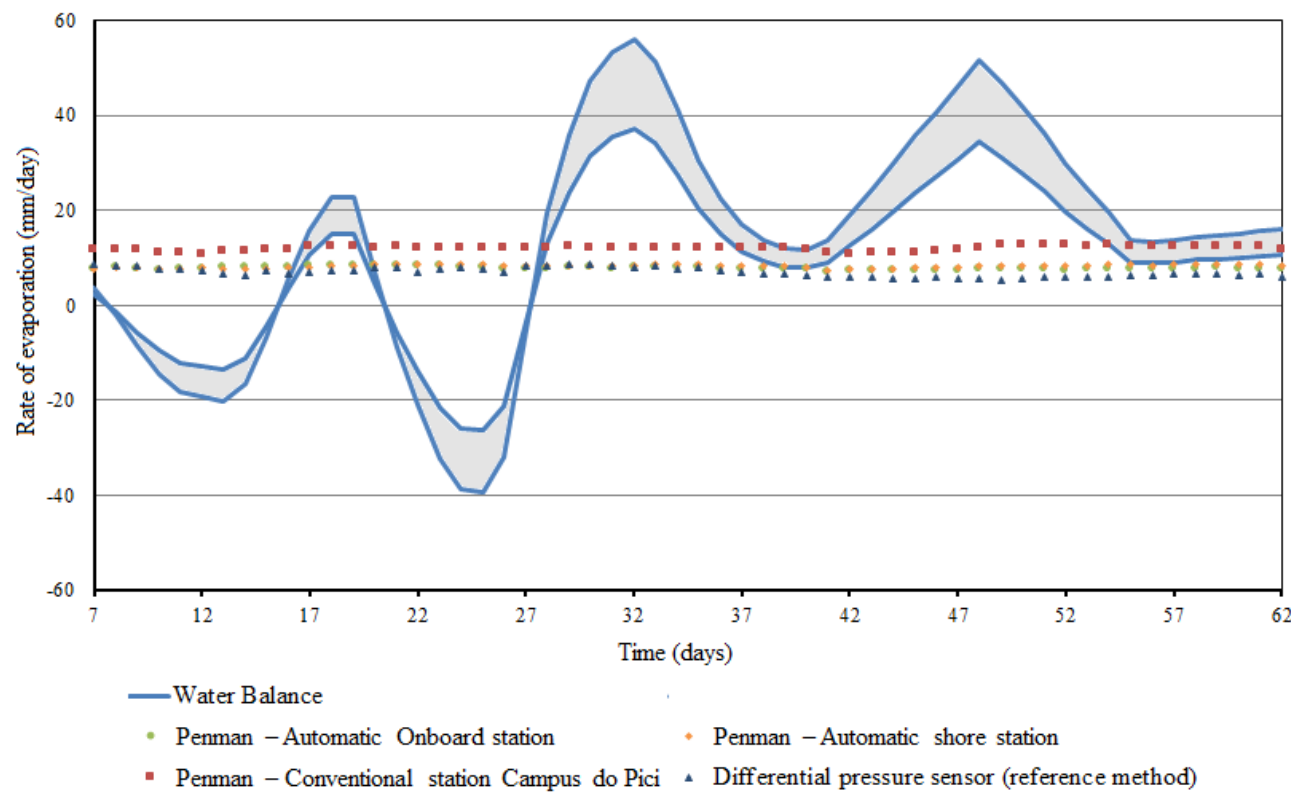

Figure 3. Daily evaporation measured at the Gavião Reservoir, Pacatuba, Ceará, Brazil, from 11 October to 11 December 2019.

The water balance method, based on daily data, presents high instability and daily results that are not satisfactory for practical application. Excessively high and excessively low values for evaporation were seen, including negative values. This would mean that there was a gain but no loss of water in the reservoir, with a variation in the daily rate of evaporation of +60 to $-40 \mathrm{~mm}^{-1 a y}{ }^{-1}$. However, the mean value for the period under analysis shows evaporation of around $14 \mathrm{~mm}^{\mathrm{day}}{ }^{-1}$, a high value, but of the same order of magnitude as the other measurements. This broad range of variation clearly indicates the uncertainty of the calculation (BIGLARBEIGI; GIULIANI; CASTELLETTI, 2018) when using the water balance for short intervals (daily intervals, for example). This can be seen even during the dry season, when the flow rate of the rivers is negligible. This uncertainty tends to be greater in the Gavião Reservoir than in other reservoirs, since it is part of the interconnected system that supplies the MRF, and is therefore supplied by other reservoirs. In reservoirs that do not receive transposed water, the uncertainty during the dry period may be lower than that seen in the present study.

The Penman method has a realistic physical basis, and is cited in the literature as best representing evaporation when compared to conventional methods for quantifying evaporation. It is, however, a method which is subject to the uncertainties of measuring climate variables. It can be seen that this method presented values for the rate of evaporation similar, albeit superior, to the reference method, especially when the estimate is based on data from the station furthest from the reservoir, in this case, the Campus do Pici.

Table 3 shows the daily rates of evaporation, as well as the total evaporated in the Gavião Reservoir from 11 October to 11 December 2019 using the different methods. 
Table 3. Mean daily rates of evaporation $(\mathrm{mm})$ and total evaporation during the study period (mm) estimated by the Penman, water balance and differential pressure sensor methods, in the Gavião Reservoir, Ceará, between 11 October and 11 December 2019.

\begin{tabular}{lcc}
\hline \multirow{2}{*}{ Method } & \multicolumn{2}{c}{ Rate of evaporation (mm) } \\
\cline { 2 - 3 } & Daily Average & Total for the period \\
\hline Differential pressure sensor method & 6.9 & 395 \\
Penman method - Onboard station & $7.7^{\text {ns }}$ & 478 \\
Penman method - Shore station & $8.2^{*}$ & 508 \\
Penman method - Station on the Campus do Pici & $11.8^{*}$ & 734 \\
Water balance method (maximum rate) & $13.7^{*}$ & 853 \\
Water balance method (minimum rate) & 9.2 & 569 \\
\hline
\end{tabular}

*The difference between the mean value for the method and for the reference method is significant by Student's ttest at $5 \%$ probability, ${ }^{\text {ns }}$ the mean value for the method and for the reference method do not differ significantly by Student's t-test at $5 \%$ probability.

Each method presented higher values for mean evaporation than the differential pressure method. Mean evaporation was overestimated by $12 \%$ using the Penman method based on data from the onboard station, which corresponds to a difference of $0.8 \mathrm{~mm} \cdot \mathrm{day}^{-1}$. This indicates a good result, and is the closest estimate to that of the of differential pressure method. Using the Penman method based on data from the station on the shore of the reservoir, the overestimation was $19 \%$, which is equal to to a difference of $1.3 \mathrm{~mm}$.day ${ }^{-1}$. Using the Penman method based on data from the furthest station $(19 \mathrm{~km})$, on the Campus do Pici, the mean evaporation was overestimated by $71 \%$, corresponding to a difference of $4.9 \mathrm{~mm}^{-d_{a y}}{ }^{-1}$, a value that is completely at odds with the other values. According to the water balance method that considers the maximum rate of evaporation, the value is overestimated by almost $100 \%$, which is equal to a difference of $6.8 \mathrm{~mm}^{-d a y}{ }^{-1}$, the worst result among the methods used. When the minimum rate of evaporation was calculated using the water balance method, the value was overestimated by $33 \%$, equal to a difference of $2.3 \mathrm{~mm}^{-\mathrm{day}^{-1}}$.

The fact that the land station installed on the Campus do Pici showed estimates for evaporation that differed from the other stations can be explained by the differences in microclimate between the measurement site and the Gavião Reservoir. Another factor is that the wind speed at the conventional station on the Campus do Pici was measured at a height of $10 \mathrm{~m}$ instead of $2 \mathrm{~m}$, and needed to be corrected by means of a model. Furthermore, on the shores of the reservoir and at the station on the Campus do Pici, the natural barriers are different and can influence wind speed, whereas for the onboard station, the barriers are very far. Another factor that may have contributed to this difference is that the global solar radiation on the Campus do Pici was calculated from the daily insolation, as per the method presented by Angstrom (1924) and Aguiar et al. (1999), which might be a source of uncertainty.
Rong et al. (2013), studying evaporation at Dongping Lake, found that the climate parameters that most help to increase evaporation are radiation balance and temperature. Dantas (2017), in his study to estimate evaporation at the Castanhão Reservoir in Ceará, found that solar radiation, maximum air temperature and relative humidity had the greatest influence on water loss through evaporation.

Using the Penman method with data from a weather station on the surface of the water and another on land, Dantas (2017) found a daily estimated rate of evaporation of $3.99 \mathrm{~mm}$ and 3.29 $\mathrm{mm}$ respectively in the Castanhão reservoir in Ceará. However, the values measured in this research by the Penman method (8-12 $\mathrm{mm} \mathrm{day}^{-1}$ ) are compatible with values estimated based on the water balance in the region (MOLLE; CADIER, 1992; ARAÚJO; GÜNTNER; BRONSTERT, 2006; CAMPOS, 2010).

Figure 4 shows the comparison between daily evaporation estimated by the reference method (differential pressure) and the evaporation estimated by the conventional Penman and water balance methods.

An analysis of the performance of each method using error and efficiency measurements, taking the differential pressure sensor as a reference, is shown in Table 4.

The values shown in Table 4 suggest that in no case was there a good adjustment, with $\mathrm{R}$ values close to zero, ranging from -0.032 to 0.155 , which indicate the low precision of the estimates for each of the methods under evaluation. The correlation coefficients $\left(\mathrm{R}^{2}\right)$ were also quite close to zero, ranging from 0.001 to 0.024 . Furthermore, the index of agreement (d) showed no satisfactory values, with each method less than 0.5 . These results indicate that both the Penman method (for the station far from the reservoir) and the water balance method estimated evaporation with little accuracy, i.e. there was a big difference between these values and thoseof the reference method. 

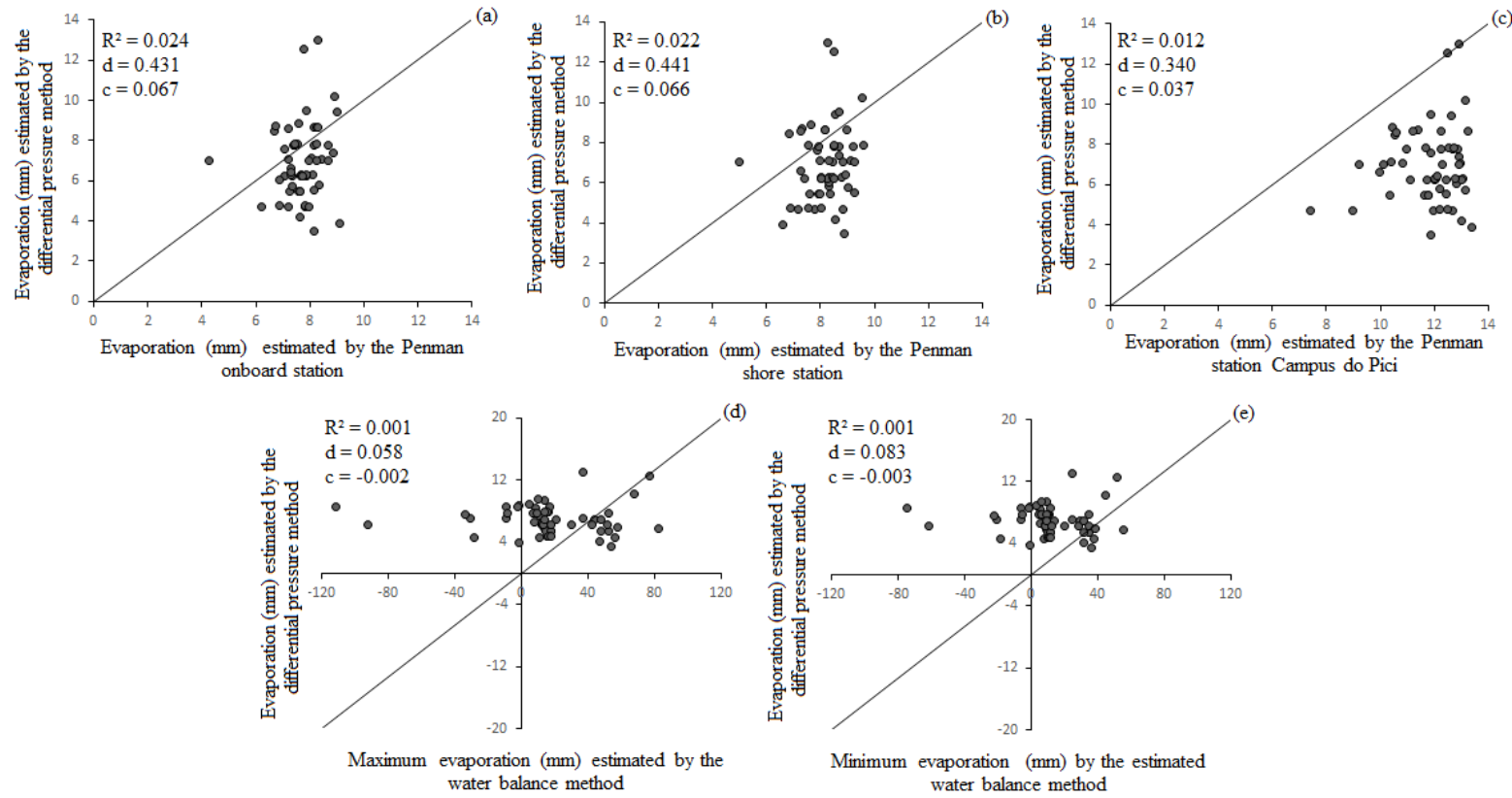

Figure 4. Comparison between the evaporation estimated by the conventional Penman and Water Balance methods and by the reference method of hydrostatic differential pressure, on a daily scale in the Gavião Reservoir, Pacatuba, Ceará, Brazil, between 11 October and 11 December 2019.

Table 4. Statistical analysis of the correlation between the conventional Penman and water balance methods and the reference method (hydrostatic pressure) on a daily scale, in the Gavião reservoir, Ceará, between 11 October and 11 December 2019.

\begin{tabular}{lcccccccc}
\hline \multirow{2}{*}{ Method } & \multicolumn{4}{c}{ Index } & \multicolumn{4}{c}{ Error } \\
\cline { 2 - 9 } & $\mathrm{R}$ & $\mathrm{R}^{2}$ & $\mathrm{~d}$ & $\mathrm{c}$ & $\mathrm{ME}$ & $\mathrm{RMSE}$ & $\mathrm{SEE}$ & $\mathrm{CRM}$ \\
\hline $\mathrm{E}_{\mathrm{PN}-\mathrm{ONB}}$ & 0.155 & 0.024 & 0.431 & 0.067 & -0.779 & 2.406 & 0.793 & -0.113 \\
$\mathrm{E}_{\mathrm{PN}-\mathrm{BNK}}$ & 0.149 & 0.022 & 0.441 & 0.066 & -1.264 & 2.287 & 1.287 & -0.183 \\
$\mathrm{E}_{\mathrm{PN}-\mathrm{PC}}$ & 0.110 & 0.012 & 0.340 & 0.037 & -4.955 & 5.378 & 5.043 & -0.716 \\
WB $_{\text {MAX }}$ & -0.032 & 0.001 & 0.058 & -0.002 & -9.701 & 34.723 & 9.875 & -1.401 \\
WB $_{\text {MIN }}$ & -0.032 & 0.001 & 0.083 & -0.003 & -4.160 & 22.674 & 4.234 & -0.601 \\
\hline
\end{tabular}

$\mathrm{E}_{\mathrm{PN}-\mathrm{ONB}}$ Penman based on data from the onboard station; $\mathrm{E}_{\mathrm{PN}-\mathrm{BNK}}-$ Penman based on data from the shore station at the reservoir; $\mathrm{E}_{\mathrm{PN}-\mathrm{PC}}-$ Penman based on data from the station on the Campus do Pici; $\mathrm{WB}_{\mathrm{MAX}}-$ Water balance (maximum rate); $\mathrm{WB}_{\mathrm{MIN}}-$ Water balance (minimum rate). $\mathrm{R}^{2}=$ coefficient of determination; $\mathrm{R}=$ Pearson correlation coefficient; $\mathrm{d}=$ index of agreement; $\mathrm{c}=$ performance index; $\mathrm{ME}=$ mean error; RMSE $=$ root mean square error; $\mathrm{SEE}=$ standard error of the estimate; $\mathrm{CRM}=$ coefficient of residual mass

In the study by Leão et al. (2013), the Penman method was considered suitable for estimating evaporation during the dry season in the Banabuiú dam, located in the semi-arid region of the northeast of Brazil, since the statistical indices indicate an 'optimal' performance for this method of estimating evaporation as a component of water balance. In Cabrera et al. (2016), the performance of the Penman method was classified as 'very good' for the central region of São Paulo (Itirapina), presenting the best indices for the dry period when the results were compared with the evaporation seen in a standard 20 $\mathrm{m}^{2}$ pan. According to Leitão, Oliveira and Leitão (2007), for the Boqueirão and Patos Reservoirs in the Cariri and Sertão regions of Paraíba, the performance of the Penman method was classified as 'good' and 'acceptable' respectively. This method had the worst performance for estimating evaporation when the results were compared with the evaporation seen in a standard $20 \mathrm{~m}^{2}$ pan.

Due to the great magnitude and oscillation of daily data with the water balance method, both hypotheses, the maximum and minimum rate, showed a high value for the RMSE, indicating that the daily evaporation estimated by this method differed greatly from that of the reference method, since this index is unfavourable to errors of higher magnitude. This indicates that the water balance method is less accurate than the Penman method, even for distant stations (in this case, $19 \mathrm{~km}$ from the reservoir). However, it can be seen that the evaporation estimated by the water balance method 
(minimum rate) presented lower values for ME, CRM and SEE than did the Penman method, based on data from the station on the Campus do Pici.

\section{VYELAS Model}

To simulate water availability in the Gavião reservoir, mean evaporation during the dry season was calculated using the different methods as shown in Table 5. In fact, the VYELAS model uses the dryseason evaporation as a central parameter (ARAÚJO; GÜNTNER; BRONSTERT, 2006; CAMPOS, 2010).

Based on the different values for estimated evaporation, the water availability (regulated flow rate associated with the $99 \%$ annual guarantee) was simulated, together with the mean evaporated flow rate, as shown in Table 6 .

Table 5. Mean evaporation during the dry season $(\mathrm{m})$ by the Penman, water balance and differential pressure sensor methods for the Gavião reservoir, Pacatuba, Ceará, Brazil.

\begin{tabular}{lc}
\hline \multicolumn{1}{c}{ Method } & Dry-season evaopration $(\mathrm{m})$ \\
\hline Differential pressure sensor method & 1.48 \\
Penman method - AWS Onboard station & 1.65 \\
Penman method - AWS Shore of the reservoir & 1.75 \\
Penman method -CWS Campus do Pici & 2.53 \\
Water balance method (maximum rate) & 2.95 \\
Water balance method (mimimum rate) & 1.97 \\
\hline
\end{tabular}

Table 6. Water availability ( $\mathrm{Q}_{\mathrm{W}}$, regulated flow rate with $99 \%$ annual guarantee, given in $\mathrm{hm}^{3}$ per year) calculated by the VYELAS Model for the Gavião Reservoir, Ceará, Brazil. The mean rate of evaporation during the dry period was taken as equal to the mean value measured by each method as used in this study (October to December 2020).

\begin{tabular}{lcccccc}
\hline \multicolumn{1}{c}{ Method for calculating evaporation $\left.{ }^{[*}\right]$} & $\mathrm{Q}_{\mathrm{W}}$ & $\overline{Q_{W}}$ & $\overline{Q_{E D}}$ & $\overline{Q_{O}}$ & $\mathrm{Q}_{\mathrm{W}} / \mathrm{Q}_{\mathrm{W} 0}$ & $\mathrm{Q}_{\mathrm{ED}} / \mathrm{Q}_{\mathrm{ED} 0}$ \\
\hline Differential pressure sensor & 5.290 & 5.264 & 9.329 & 17.621 & $100 \%$ & $100 \%$ \\
Penman - AWS onboard station & 4.580 & 4.558 & 10.316 & 17.484 & $87 \%$ & $111 \%$ \\
Penman - AWS Shore of the reservoir & 4.240 & 4.219 & 10.868 & 17.386 & $80 \%$ & $116 \%$ \\
Penman method -CWS Campus do Pici & 0.840 & 0.836 & 15.150 & 16.172 & $16 \%$ & $162 \%$ \\
Water balance (maximum rate) & 0.019 & 0.019 & 17.107 & 15.800 & $0.4 \%$ & $183 \%$ \\
Water balance (mimimum rate) & 3.210 & 3.195 & 12.145 & 17.406 & $61 \%$ & $130 \%$ \\
\hline
\end{tabular}

${ }^{\left[{ }^{*}\right]} \mathrm{Q}_{\mathrm{W} 0}=$ water availability calculated based on the reference data; $\mathrm{Q}_{\mathrm{ED}}=$ mean evaporated flow rate during the dry season; $\mathrm{Q}_{\mathrm{ED} 0}=$ evaporated flow rate during the dry season calculated based on the reference data; $\mathrm{Q}_{\mathrm{O}}=$ spill rate (bleed rate).

The estimates of mean evaporated flow rate vary between 17.1 and $9.3 \mathrm{hm}^{3} \mathrm{yr}^{-1}$. The mean evaporated flow rate estimated by the water balance method, considering the maximum rate of evaporation, overestimated the reference flow rate by $83 \%$. The evaporated flow rate estimated by the Penman method suggests a divergence of $11 \%, 16 \%$ and $62 \%$ in relation to the reference evaporation from the on-board automatic station, the automatic station installed on the shore of the reservoir, and the conventional station on the Campus do Pici respectively. This shows that the results for the two stations close to the lake (onboard or on the shore) are acceptable. However, the two methods that are usually suitable for calculating evaporation, the water balance method ignoring infiltration, and Penman's method for data from a land station far from the reservoir $(19 \mathrm{~km})$, generated unacceptably high values that were completely at odds with the other values.

When estimating water availability, the Penman method for the data from stations close to the reservoir (on board and on the shore) differs at most by $20 \%$ compared to the reference method. For the distant land station, the estimate of water availability was incongruous, indicating a value of only $16 \%$ compared to the reference. The water balance method, which is often used in the region due to the lack of consistent data, proved unsuitable for estimating water availability: for the zeroinfiltration hypothesis, the value would be only $0.4 \%$ of the reference value, while for the high-infiltration hypothesis (equal to the evaporation), it would be only $16 \%$ of the reference value.

Based on the data in Table 6, it can be said that the intrinsic water availability (associated with a $99 \%$ annual guarantee) of the Gavião Reservoir (i.e. without including the water imported from other 
sources) is $5.29 \mathrm{hm}^{3}$ per year. If the Penman method were used for the onboard station, water availability would be estimated at only $4.58 \mathrm{hm}^{3}$ per year. The difference $\left(0.71 \mathrm{hm}^{3}\right.$ per year) is low, equal to the supply of less than six thousand inhabitants; however, when evaluating evaporation based on the Penman method for a station far from the reservoir, water availability would be estimated at only $0.84 \mathrm{hm}^{3}$ per year. The considerable difference $\left(4.45 \mathrm{hm}^{3}\right.$ per year) would be enough to supply a population of almost 35 thousand inhabitants, for example. In other words, if the decision makers used the Campus do Pici station as a reference to assess water availability in the Gavião Reservoir, they would provide only $16 \%$ of the water that could actually be made available. This difference is less serious when the rate of evaporation is calculated using the water balance (minimum rate). According to Table 6 , the water availability would be only $3.21 \mathrm{hm}^{3}$ each year. The difference between this estimate and the most consistent $\left(5.29 \mathrm{hm}^{3} \cdot \mathrm{yr}^{-1}\right)$ would supply around 16 thousand inhabitants.

Considering that the two above-mentioned methods (Penman with a distant weather station and the water balance method) are often used to make decisions regarding water management in the northeast of Brazil due to the scarcity of data in semi -arid regions (ALAZARDA et al. 2015), the present study demonstrates the importance of having more robust methods for estimating rates of evaporation (ALTHOFF et al. 2019), such as remote sensing (LOSGEDARAGH; RAHIMZADEGAN, 2018). It is also necessary to assess the importance of understanding evaporation in view of climate change scenarios (FIROOZI; ROOZBAHANI; BAVANI MASSAH, 2020) and the increased pollution of surface reservoirs (MESQUITA et al. 2020).

\section{CONCLUSIONS}

Using data from the onboard station, the Penman method gave a result closer to that of the reference method (differential pressure sensor), showing it to be the most favourable on a daily scale, and a good alternative to the direct method of measuring evaporation. Based on the data collected in this study, it can be said that two methods which are widely used in the semi-arid region of Brazil to evaluate evaporation, namely, (1) water balance with the negligible-infiltration hypothesis, and (2) the Penman method based on data from land stations far from the reservoir, presented excessively high values for evaporation, and cannot therefore be used on a daily time scale. The above methods also presented highly differing estimates of water availability, and proved to be unacceptable. As such, it is recommended that for calculating daily evaporation using the traditional Penman method, when it is not possible to install a station on the surface of the water, data from weather stations as close as possible to the water be used.

\section{ACKNOWLEDGEMENTS}

The authors wish to thank $\mathrm{CNPq}$ for the scholarship that helped in carrying out this study and for the resources that financed project 407999/20167. The authors also wish to thank CAPES for its continued support of the Graduate Program in Agricultural Engineering of UFC, and the PRINT/ UFC Program, process 88881.311770 / 2018-01, which financed the arrival of our German partners. Our thanks also go to Professors Amin Raabe and Peter Holstein for their help in adjusting the equipment and with the field work.

\section{REFERENCES}

AGUIAR, J. V. et al. Estimativa da radiação solar a partir da insolação, na Região Metropolitana de Fortaleza, CE. In: CONGRESSO BRASILEIRO DE AGROMETEOROLOGIA, 11., 1999, Florianópolis. Anais... Florianópolis: SBAGRO, 1999.

ALAZARDA, M. et al. Estimatingevaporation in semi-aridareasfacing data scarcity: Example of the El Haouareb dam (Merguellil catchment, Central Tunisia). Journal of Hydrology: Regional Studies, 3: 265-284, 2015.

ALTHOFF, D. et al. Improving methods for estimating small reservoir evaporation in the Brazilian Savanna.Agricultural Water Management, 216: 105-112, 2019.

ANGSTROM, A. Solar and terrestrial radiation. Quarterly Journal of the Royal Meteorological Society, 50: 21-125, 1924.

ARAÚJO, J. C.; MAMEDE, G. L.; LIMA, B. P. Hydrological guidelines for reservoir operation to enhance water governance: application to the Brazilian Semiarid Region. Water, 10: 1628-1639, 2018.

ARAÚJO, J. C.; GÜNTNER, A.; BRONSTERT, A. Loss of reservoir volume by sediment deposition and its impact on water availability in semiarid Brazil. Hydrological Sciences Journal, 51: 157-170, 2006.

BIGLARBEIGI, P.; GIULIANI, M.; CASTELlETTI, A. Partitioning the impacts of streamflow rate and evaporation uncertainty on the 
operations of multipurpose reservoirs in arid regions. Journal of Water Resources Planning Management, 144: 1-12, 2018.

CABRERA, M. C. M.et al.Performance of evaporation estimationmethods compared with standard $20 \mathrm{~m}^{2}$ tank. Revista Brasileira de Engenharia Agrícola e Ambiental, 20: 874-879, 2016.

CAMARGO, A. P; SENTELHAS, P. C. Avaliação do desempenho de diferentes métodos de estimativas da evapotranspiração potencial no Estado de São Paulo, Brasil. Revista Brasileira de Agrometeorologia, 5: 89-97, 1997.

CAMPOS, J. N. B. Modeling the yield-evaporationspill in the reservoir storage process: The regulation triangle diagram. Water Resources Management, 24: 3487-3511, 2010

CHOW, V. T.; MAIDMENT, D. R.; MAYS, L. W. Applied hydrology. 1 ed. New York:McGraw-Hill Science/Engineering/Math, 1988. 572 p.

COGERH. Portal Hidrológico. Disponível em: $<$ http://www.hidro.ce.gov.br/>. Acesso em: $12 \mathrm{dez}$. 2019.

DANTAS, S. P. Açudagem no Nordeste brasileiro e no Ceará: estimativa de evaporação do açude Castanhão em um ano seco. 2017. 196 f. TESE (Doutorado em Geografia: Área de Concentração em Dinâmica Ambiental e Territorial do Nordeste Semiárido), Universidade Federal do Ceará, Fortaleza, 2017.

FIROOZI, F.; ROOZBAHANI, A.; BAVANI MASSAH, A. R. Developing a framework for assessment of climate change impact on thermal stratification of dam reservoirs. International Journal of Environmental Science and Technology, 17: 2295-2310, 2020.

LEÃO, R. A. O. et al. Estimativa da evaporação no açude Banabuiú, no Estado do Ceará, por diferentes métodos combinados, derivados da equação de Penman. Engenharia Agrícola, 33:129-144, 2013.

LEITÃO, M. M. V. B. R.; OLIVEIRA, G. M.; LEITÃO, T. J. V. Avaliação do desempenho de diferentes métodos de estimativa da evaporação para duas regiões da Paraíba. Revista Brasileira de EngenhariaAgrícola e Ambiental, 11: 585-593, 2007.

LOSGEDARAGH, S. Z; RAHIMZADEGAN, M. Evaluation of SEBS, SEBAL, and METRIC models in estimation of the evaporation from the freshwater lakes (Case study: Amirkabir dam, Iran). Journal of Hydrology, 561: 523-531, 2018.

MAMEDE, G. L. et al. Overspill avalanching in a dense reservoir network. Proceedings of the National Academy of Sciences of the United States of America, 109: 7191-7195, 2012.

MCJANNET, D. L. et al. Measurements of evaporation from a mine void lake and testing of modelling approaches. Journal of Hydrology, 555: 631-647, 2017.

MESQUITA, J. B. et al. The influence of hydroclimatic conditions and water quality on evaporation rates of a tropical lake. Journal of Hydrology, 590: 1-13, 2020.

MOLLE, F.; CADIER, E. Manual do pequeno açude. 1. ed. Recife: SUDENE/ CooperaciónFrançaise/ORSTOM, 1992. 528 p.

PADRÓN, R.S.et al. Observed changes in dryseason water availability attributed to humaninduced climate change. Nature Geosciences, 13: 477-481, 2020.

PENMAN, H. L. Natural evaporation from open water, bare soil and grass. Proceedings of the Royal Society, 193: 120-145, 1948.

RONG, Y. et al. Effects of climate variability on evaporation in Dongping Lake, China, during 2003 2010. Advances in Meteorology, 2013: 1-11, 2013.

VIEIRA, N. P. A. et al. Estimativa da evaporação nos reservatórios de Sobradinho e Três Marias usando diferentes modelos. EngenhariaAgrícola, 36: 433-448, 2016.

WMO - World Meteorological Organization. Guide to meteorological instruments and methods of observation, 2018 ed. Geneva: WMO-No. 8, 2018. $1177 \mathrm{p}$.

WILLMOTT, C. J.; ACKLESON, S. G.; DAVIS, R. E. Statistics for the evaluation and comparison of models. Journal of Geography Research, 90: 89959005, 1985.

$\mathrm{XU}, \mathrm{C}$. et al. Future of the human climate niche. Proceedings of the National Academy of Sciences of the USA, 117: 11350-11355, 2020. 